\title{
Invasion of Erigeron annuus (L.) Pers. in the hay and pasture meadows of the Greater Caucasus: modeling of the current and predicted distribution
}

\author{
Rustam Pshegusov ${ }^{1,}$, , Khusen Nazranov ${ }^{2}$, Victoria Chadayeva ${ }^{1}$, and Beslan Nazranov ${ }^{2}$ \\ ${ }^{1}$ Tembotov Institute of Ecology of Mountain Territories of the Russian Academy of Sciences, 360051 \\ Nalchik, I. Armand St.37a, Russia \\ ${ }^{2}$ Kabardino-Balkarian State Agrarian University named after V.M. Kokov, 360030 Nalchik, Lenin \\ Ave. 1V, Russia
}

\begin{abstract}
Erigeron annuus (L.) Pers is a North American invasive species that invades hay meadows and pastures from the plain to the high mountainous zone of the Caucasus. Leads to a decrease in biodiversity and forage value of meadows. Predictive modeling using the MaxEnt method showed that at present, in the valleys of large rivers of the Caucasus, there are significant areas potentially suitable for the growth of this species (only 10.4 thousand $\mathrm{km}^{2}$ ). The spatial distribution of $E$. annuus is limited by the wind speed in January (no more than $2.6 \mathrm{~m} / \mathrm{s}$ ), the maximum temperature in April $\left(13-16{ }^{\circ} \mathrm{C}\right)$, the amount of precipitation in the wettest months $(80-$ $100 \mathrm{~mm})$ and quarter $(240-260 \mathrm{~mm})$. In accordance with the predicted trends of climatic changes, by 2050 the total area of habitats suitable for the species may be doubled (up to $20.3 \mathrm{~km}^{2}$ ).
\end{abstract}

\section{Introduction}

A serious problem widely discussed by the world community is biological invasions one of the main biogenic threats to biodiversity, food security and economic well-being of individual countries and the planet as a whole [1,2; and etc.]. At the same time, an important direction of research is the study of the patterns of distribution of invasive species, including mountainous regions, in the background of modern climatic changes and the increasing anthropogenic load on natural ecosystems [3-5; and etc.].

Erigeron annuus (L.) Pers. (Stenactis annua Gass., Phalacroloma annuum (L.) Dumort.). - an aggressive invasive species that massively litters hayfields and pastures from the lowlands to the middle mountains of the Greater Caucasus, significantly reducing their food value (in fresh form, it is practically not eaten by animals) [6]. At present, it is intensively spreading in the highlands (up to $2300 \mathrm{~m}$ above sea level), and it can significantly damage the Caucasian regions, especially the developed system of distant pasture breeding in mountainous regions.

The regions of the Caucasus have a wide range of natural and climatic conditions, which can ensure the success of naturalization of E. annuus. In this regard, it is important to

\footnotetext{
*Corresponding author: p_rustem@inbox.ru
} 
study the bioclimatic and ecological-geographical requirements of the species to identify potential habitats and possible scales of distribution, including the high-mountainous regions of the Caucasus. Accordingly, the aim of the research is to carry out spatial modeling of the modern distribution of E. annuus in the Caucasus, to predict a possible change in the species range until 2050 against the background of modern climatic changes.

\section{Methods and materials}

E. annuus is an annual plant (Asteraceae Dumort.) native to eastern North America. The species is ubiquitous in North America, in 27 European countries, in Japan, Korea, New Zealand [7]. It is able to grow in disturbed habitats, in meadows, in steppes, in forests. When growing on agricultural fields, the dry weight of the species reaches $468 \mathrm{~kg}$ per hectare with a significant removal of microelements from the soil [8].

To model the E. annuus distribution in the Caucasus, during ground-based studies, GPS coordinates of 60 habitats of the species were recorded. The total area of the analyzed territory was 390 thousand $\mathrm{km}^{2}$ (Fig. 1).

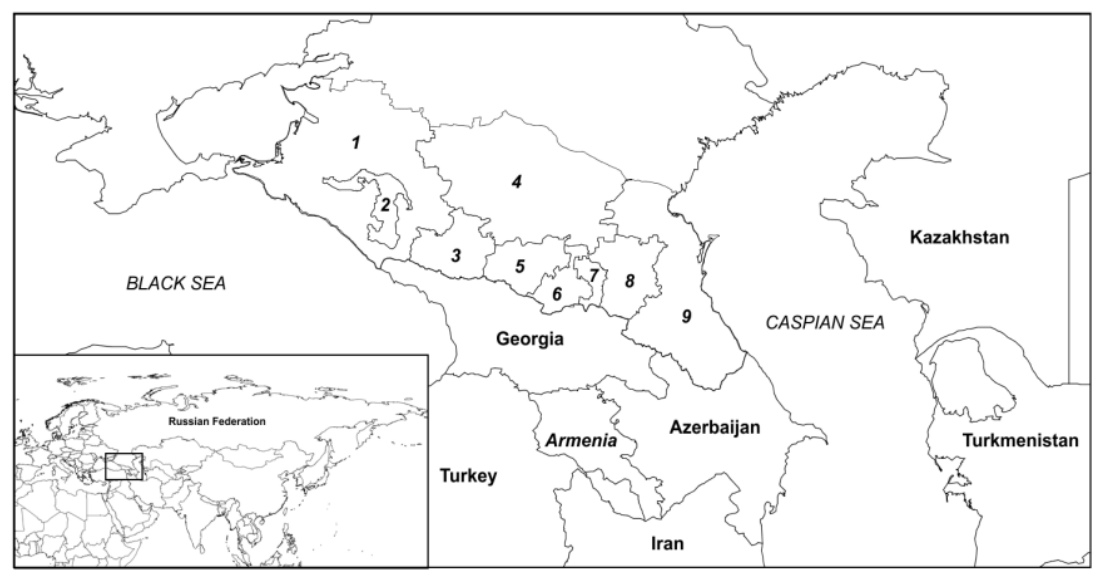

Fig 1. Location and schematic map of the research area. 1 - Krasnodar region, 2 - Republic of Adygea, 3 - Karachai-Cherkess Republic, 4 - Stavropol region, 5 - Kabardino-Balkar Republic, 6 Republic of North Ossetia - Alania, 7 - Ingush Republic, 8 - Chechen Republic, 9 - Republic of Dagestan.

As a basis for interpolation of data on spatial distribution, multispectral scenes of Landsat satellites, data of radar topographic survey (SRTM) and climate models of WorldClim were used [9, 10]. In total, about 140 bioclimatic and ecological-geographical variables were used in the work. Predictive modeling of the distribution of E. annuus was carried out using the linear Maxent method (Maxent software for species habitat modeling) [11]. The Maxent methods allow identifying habitats similar to those in which the species was identified based on the distributions of the values of environmental properties. The graphic representation of the research results is formulated in the creation of maps of the distribution of the species in the GIS environment of the MapInfo 10 application. The visualization of the probability of occurrence is realized by ranked values in the gradation of colors from blue (occurrence "0") to red (occurrence "1"). For potentially suitable habitats of the species, probability values are acceptable from 0.5 to 0.8 , for optimal habitats - above 0.8 . This approach makes it possible to identify environmental parameters that affect the distribution of the species. 
To assess the dynamics of the E. annuus range, considering climate changes until 2050, we used forecast models developed on the basis of the most optimistic scenario of changes in the concentration of greenhouse gases - RCP2.6, adopted by the Intergovernmental Panel on Climate Change (IPCC) in the preparation of its Fifth Report in 2014 (Fifth Assessment Report (AR5)). According to the RCP2.6 scenario, greenhouse gas emissions will peak in 2010-2020, after which there will be a decline, and an increase in the global average surface temperature at the end of the current century (2081-2100) compared to its beginning (1986-2005) will be in the range of $1.4-3.1^{\circ} \mathrm{C}$ with an average level of $2.2^{\circ} \mathrm{C}$.

\section{Results and discussion}

The habitats of E. annuus suitable for bioclimatic conditions are concentrated from the foothill to mid-mountain zones of the Greater Caucasus and along the Black Sea coast (Fig. 2). Optimal habitats are noted in the valleys of large rivers up to the high mountains. High AUC values (0.978), characterizing the accuracy of the determination, indicate a fairly high predictive ability of the model.

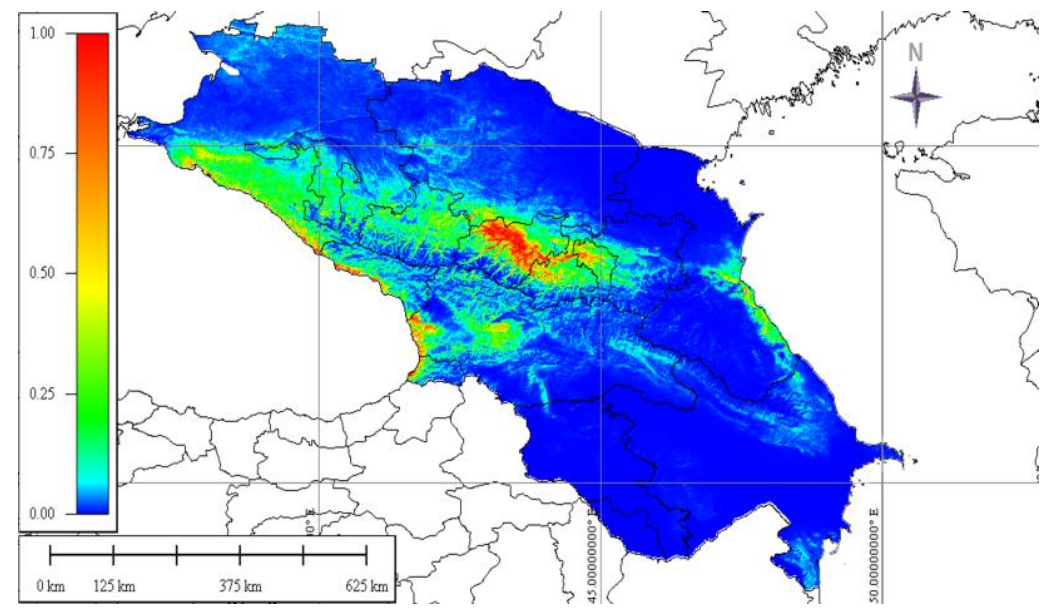

Fig. 2. Skeleton map on distribution of Erigeron annuus adequate habitats. 0-0.4 - values of probable inadequate habitats, $0.5-0.8$ and over 0.8 - values of probable adequate and optimal habitats.

At the moment, the areas potentially suitable for E. annuus within the boundaries of the habitat of the studied territories is 10.41 thousand $\mathrm{km}^{2}$ (that is, $2.67 \%$ of the studied territory), of which 4.1 thousand $\mathrm{km}^{2}$ is the area that makes up the optimal habitat properties with the possibility of identifying the species $80-100 \%$. The significant distribution area of the species covers the Central and Eastern Caucasus within the borders of Kabardino-Balkaria, North Ossetia, Ingushetia and Chechnya, as well as the adjacent regions of Karachay-Cherkessia and the Black Sea coast (Krasnodar Territory, Abkhazia) from the west.

The most important factors that together have the greatest influence on the distribution of E. annuus in the Caucasus (the highest coefficient of permutation), climatic parameters wind1, bio16, bio13, tmax4, wind3 are found (table).

Table. Contribution of abiotic factors to formation of Erigeron annuus distribution area within the Caucasus.

\begin{tabular}{|c|c|c|}
\hline Parameters & Contribution to modeling, $\%$ & Permutation coefficient, $\%$ \\
\hline wind 1 & 10.4 & 17.7 \\
\hline
\end{tabular}




\begin{tabular}{|c|c|c|}
\hline bio16 & 3.2 & 13.2 \\
\hline bio13 & 0.4 & 11.7 \\
\hline $\operatorname{tmax} 4$ & 1.4 & 10.4 \\
\hline wind3 & 7.5 & 9 \\
\hline
\end{tabular}

Note. wind 1 and wind 3 is wind speed $(\mathrm{m} / \mathrm{s})$ of January and March, respectively; bio13 and bio16 is precipitation of the most humid month and the most humid quarter $(\mathrm{mm})$; tmax4 is maximum temperature in April $\left({ }^{\circ} \mathrm{C}\right)$.

The predicted suitability of the habitat for E. annuus generally decreases with an increase in wind speed in January and March over 2.6-2.7 m/s, as well as at a maximum April temperature of less than 13 and over $16{ }^{\circ} \mathrm{C}$. The acceptable range of precipitation is rather narrow $-80-100 \mathrm{~mm}$ for the wettest month and $240-260 \mathrm{~mm}$ for the wettest quarter. $E$. annuus is a plant that survives the winter period in the form of seeds, less often rosette shoots formed in autumn [12]. The indicated ranges of the temperature factor and wind speed with a cooling effect are likely to ensure the maintenance of conditions favorable for the preservation of seeds and survival of shoots in the winter-spring period. The limited distribution of E. annuus in the flat zone of the Greater Caucasus regions, as well as in the Ciscaucasia (Stavropol Territory) and Dagestan, is probably due to the dry climate of these regions. Thus, during the wettest summer period, only $130-200 \mathrm{~mm}$ of precipitation falls on the plains of the Central Caucasus, which is less than the value acceptable for E. annuus growth. The average annual precipitation in the steppe landscapes of the Ciscaucasia does not exceed $200-350 \mathrm{~mm}$ in the east and $450-600 \mathrm{~mm}$ in the middle and western parts. Such arid conditions are typical for the lowlands and middle mountains of Dagestan, the coast of the Caspian Sea (370-600 mm of precipitation per year). Factors such as altitude, exposure and slope steepness do not significantly affect the distribution of the species. Therefore, the penetration of $E$. annuus into the mountains mainly along the gentle valleys of large rivers is probably due to the transfer of seeds along a developed transport network.

By 2050, an increase in the area of habitats potentially suitable for the growth of $E$. annuus is predicted by 1.95 times (up to 20.3 thousand $\mathrm{km}^{2}$ or $5.20 \%$ of the study area), the best places of distribution -2.48 times (up to 9.9 thousand $\mathrm{km}^{2}$ or $2.55 \%$ of the territory). It is possible to capture new vast territories in the Western Caucasus (Karachay-Cherkessia, Krasnodar Territory, Adygea) with the formation of a second center of the area (center of abundance) on the Black Sea coast (Krasnodar Territory, Abkhazia, Georgia) (Fig. 3). As in the territory of the regions of the Central and Eastern Caucasus (Kabardino-Balkaria, North Ossetia, Ingushetia, the Chechen Republic), it is predicted that the species will move to mountainous regions. The dynamics of distribution of E. annuus in the Ciscaucasia and on the coast of the Caspian Sea (Stavropol Territory, Dagestan) is poorly expressed.

Similar studies conducted for different invasive species in the mountains of China and the Himalayas $[13,14]$ also showed that the risk of biological invasions will constantly increase in the coming decades, and the invasion of alien plant species into mountains as a result of climate change is a large-scale process. 


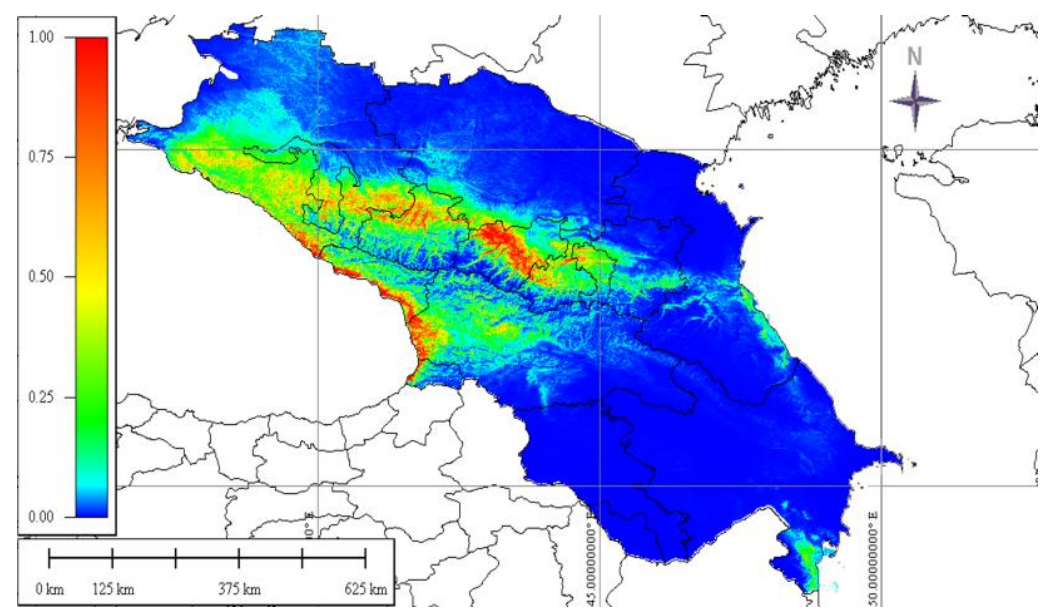

Fig 3. Skeleton map of distribution of favorable E. annuus habitats in the Caucasus by 2050 in view of climate changes according to the scenario RCP 2.6 (IPSL-CM5 model). 0-0.4 - values of probable inadequate habitats, $0.5-0.8$ and over 0.8 - values of probable adequate and optimal habitats.

\section{Conclusions}

The spatial distribution of E. annuus in the Caucasus is most limited by wind speed in January and March (no more than 2.6-2.7 m/s), precipitation in the wettest month and in summer (80-100 $\mathrm{mm}$ and 240-260 $\mathrm{mm}$, respectively), the maximum temperature in April $\left(13-16^{\circ} \mathrm{C}\right)$. Values of wind speed and temperature regimes acceptable for the species in winter and spring periods, possibly, provide situations suitable for overwintering seeds and autumn shoots, and the probability of population recovery in the subsequent growing season.

At present, the center of the E. annuus habitat in the Greater Caucasus is located in the eastern and central parts (North Ossetia, Kabardino-Balkaria, Chechnya, Ingushetia); there is a great possibility of its identification also along the Black Sea coast (Abkhazia, Krasnodar Territory). The total area of permissible habitat for the species in the region is $10.41 \mathrm{~km}^{2}$, of which $4.1 \mathrm{~km}^{2}$ are the best for growth. In accordance with the most optimistic scenario of climatic changes, by 2050 in the Caucasus there will be an expansion of the range of suitable and best places for E. annuus by 1.96 and 2.49 times, respectively. The mass distribution of E. annuus is predicted in the Western part of the Caucasus (Adygea, Krasnodar Territory, Karachay-Cherkessia) with the formation of the second center of the range on the Black Sea coast (Abkhazia, Krasnodar Territory, Georgia), and the widespread penetration of the species into high-mountainous regions.

\section{References}

1. P. Pyšek, V. Jarošík, P.E. Hulme, J. Pergl, M. Hejda, U. Schaffner, M. Vilà, Glob Chang Biol. 18, 1725-1737 (2012)

2. D.A. Wardle, D.A. Peltzer, Biol. Invasions. 19, 3301-3316 (2017)

3. K.L. McDougall, J.M. Alexander, S. Haider, A. Pauchard, N.G. Walsh, C. Kueffer, Divers. Distrib. 17, 103-111 (2010)

4. F. Pollnac, T. Seipel, Ch. Repath, L.J. Rew, Biol. Invasions. 14, 1753-1763 (2012) 
5. R.H. Pshegusov, V.A. Chadaeva, A.L. Komzha, Russ J Biol Invasions 11, 74-84 (2019)

6. V.A. Chadaeva, S.H. Shhagapsoev, N.L. Tsepkova, K.A. Shhagapsoeva, Russ J Biol Invasions 10, 269-281 (2019)

7. D. Frey, M. Baltisberger, P.J. Edwards, BOT HELV 113, 1-14 (2003)

8. V.A. Kozhaev, Izvestiya Gorskogo GAU 51(1), 26-32 (2014)

9. R.J. Hijmans, S.E. Cameron, J.L. Parra, P.G Jones, Int J Climatol 25, 1965-1978 (2005)

10. R.A. Baldwin, Entropy 11, 854-866 (2009)

11. D. N. Kozlov, M. Yu. Puzachenko, M.V. Fedyaeva, Yu.G. Puzachenko, Izvestia RAN. Geographic Series 4, 112-124 (2008)

12. N.N. Panasenko, Bulletin of the Bryansk Branch of the RBO 1(13), 44-51 (2018)

13. Y.B. Yang, G. Liu, X. Shi, W. Zhang, X. Cai, Zh. Ren, N. Yao, Zh. Zhu, H. Nieet, Int J Environ Res 12, 929-938 (2018)

14. P. Lamsal, L. Kumar, A. Aryal, K. Atreya, Ambio 47(6), 697-710 (2018) 